\title{
Fiscal Policy and Balance of Payments in Nigeria
}

\section{Inimino, Edet Etim ${ }^{1}$ Brown, Uduakobong Akpanabba ${ }^{2}$ Otubu, Osaretin Paul ${ }^{3}$}

Department of Economics, Faculty of Social Sciences, University of Uyo, Nigeria. Email:clergyedet1@yahoo.com Tel:+2s4706188792

Email:paulotubu@gmail.com Tel: +2348066133035

'Akwa Ibom State College of Science and Technology, Nung Ukim, Ikono, Nigeria.

:Email:udvabba@gmail.com Tel: +2s4802105s742

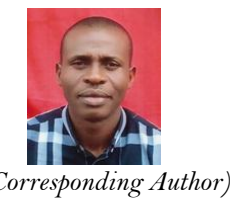

( Corresponding Author)

\begin{abstract}
This study investigated the effect of fiscal policy on balance of payments in Nigeria. The data for the study were obtained from the statistical bulletin of Nigeria's apex bank spanning 1980 to 2017. The study employed Augmented Dickey-Fuller (ADF) and Autoregressive Distributed Lag (ARDL) Bounds techniques. The result of the ADF test revealed that the variables were stable at order one and zero. The ARDL results showed that in the long run, corporate income tax, government capital expenditure and external debt have positive and significant effect on Nigeria's balance of payments. Meanwhile, exchange rate has a negative and significant effect on balance of payments in Nigeria. It also revealed that in the short run, corporate income tax and government capital expenditure have positive and significant effect on balance of payments in Nigeria. However, exchange rate and external debt have negative and significant effect on balance of payments in Nigeria. Therefore, this study concluded that fiscal policy has a meaningful effect on Nigeria's balance of payments during the period of study. This means that fiscal policy is effective in achieving a satisfactory balance of payments in the country.
\end{abstract}

Keywords: Fiscal policy, Balance of payments, ARDL, Corporate income tax, External debt and government capital expenditure. JEL Classification: E62; F32.

Citation | Inimino, Edet Etim; Brown, Uduakobong Akpanabba; Otubu, Osaretin Paul (2020). Fiscal Policy and Balance of Payments in Nigeria. Asian Journal of Economics and Empirical Research, 7(2): 207-216.

History:

Received: 8 June 2020

Revised: 13 July 2090

Accepted: 11 August 2020

Published: 31 August 2020

Licensed: This work is licensed under a Creative Commons Attribution 3.0 License (cc) Er

Publisher: Asian Online Journal Publishing Group
Acknowledgement: All authors contributed to the conception and design of the study.

Funding: This study received no specific financial support

Competing Interests: The authors declare that they have no conflict of interests.

Transparency: The authors confirm that the manuscript is an honest, accurate, and transparent account of the study was reported; that no vital features of the study have been omitted; and that any discrepancies from the study as planned have been explained.

study as planned have been explained.
Ethical: This study follows all ethical practices during writing.

\section{Contents}

1. Introduction 208

2. Literature Review

3. Methodology

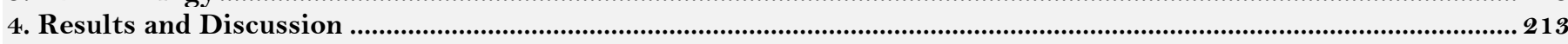

5. Conclusion and Recommendations....

References... 


\section{Contribution of this paper to the literature}

The study contributes to the existing literature by examining how Nigeria's balance of payments can be influenced with the aid of fiscal policy variables - government capital expenditure, corporate income tax and external debt. Accordingly, the study shows that fiscal policy is effective in achieving favourable BOPs in Nigeria.

\section{Introduction}

Every economic system irrespective of its political arrangement has to identify its economic goals. The major economic goals include full employment, adequate economic growth, price stability and equilibrium in the balance of payments (BOPs). These goals are usually achieved through the formulation and implementation of economic policies, especially fiscal policy. Economic policy means efforts made by all governments to direct their economies toward a high level of economic performance. Meanwhile, fiscal policy refers to the manipulation of expenditure resources and taxation powers by the government for the purpose of managing the economy (Umo, 2012). In the views of Conway (2009) fiscal policy refers to decisions a government takes about what to spend its money on, how to raise taxes and how much to borrow. It is concerned with how the agencies responsible for the conduct of fiscal policy manipulate a set of macroeconomic variables to achieve some desired objectives of policy. In Nigeria, as in other countries, it is the duty of the central government to initiate policies that will help to achieve basic macroeconomic objectives, including equilibrium in the BOPs. According to Umo (2012) "balance of payments statement is an annual summary of a country's trade and finance accounts showing receipts from, and payments to, the outside world". A typical BOPs statement consists of the capital account, current account and monetary transactions account (Gbosi, 2011). One of the macroeconomic problems facing modern nations including Nigeria is balance of payments disequilibrium. Therefore, achieving BOPs equilibrium is considered one of the major economic goals of Nigeria. According to Ekine (2011) the current account of Nigeria's BOPs was under pressure from 1997 to 2007. The pressure on the current account largely reflected the pitiable performance of the non-oil exports, the fluctuation in crude oil export, the chronic deficit of the services account and low level of unrequited transfers from abroad. Fluctuations in crude oil account exports have often led to wide swings in the current account. The services account in the current account remained in persistent deficit as a result of the low level of receipts and huge payments in respect of international services as well as the unsustainable high level of external debt falling due, especially in recent years. The low level of receipts is attributed to the fact that the transportation of Nigerians' merchandise trade and passengers is performed largely by non-resident carriers. Also, more Nigerians travel abroad than foreigners visit Nigeria. Thus, the net position of non-factor services is not in Nigeria's favour. Worse still, the non-involvement of Nigerians in direct investment in companies abroad, have made receipts in respect of factor services to be extremely low.

Moreover, from 1985 to 2007 , the capital account, excluding financing items (i.e., exceptional financing and reserves), remained very weak, except in 1994 and 1998. The weakness of the capital account arose from the low level of long-term capital inflow in the form of the direct investments and drawings on project-tied loans. In contrast, capital outflows in the form of loan repayments and short-terms capital movements have been substantial. For example, between 1980 and 1994, net transfers on long term debt averaged \$3, 198 million. If interest payments and direct investments are added, net transfers abroad would rise to \$4, 450.4 million (Ekine, 2011; Nwokpara, 1997). The trend is particularly disturbing for a foreign exchange constrained economy like Nigeria.

In addition, the dwindling stock of the country's external reserves remains disturbing. In 1992, for instance, following the Nigeria's apex bank undertaking to meet the needs of all foreign exchange users who could provide naira cover and the need to meet obligations arising from the Zero-coupon debt buy-back scheme, external reserves declined sharply to $\$ 712$ million, enough to cover only 12 Months of imports. In a number of years, reserves have also been run down to cover deficit. For instance, the then Governor of Central Bank of Nigeria (CBN), Chief Joseph Sanusi stated (in Punch newspaper, October 3, 2002) that the federal government’s $\$ 80$ billion deficit recorded in the first half of 2002 was financed from external reserves, which consequently suffered a drawdown of $\$ 2$ billion within seven months. The reserves, which peaked at $\$ 10.27$ billion in December, 2001 dropped to $\$ 8.67$ billion in July, 2002. The external reserves were $\$ 7.29$ billion as at September, 2002.

A report from the CBN in 2013 revealed that Nigeria's external sector has been facing continual variability on her overall BOPs and this has called for worry and questions on the likely causes of this instability. In 2013, for instance, the country's external sector recorded overall BOPs deficit equivalent to $0.2 \%$ of the country's gross domestic product. The event reflected, largely, increasing foreign debt, drop in external reserves and increased deportation of investment income by external (overseas) investors. Momentously, the unfavourable trends in the country's BOPs have posed severe limitations for the accumulation of foreign exchange necessary for growth and development. As a result, foreign exchange inflow and the amount available to service the economy have declined over the years. The picture of the country's earnings, which has been under pressures since the beginning of 2002 , showed that $\$ 3.796$ billion as recorded as inflows, while outflows totaled $£ 5.797$ billion.

As revealed by the Central Bank of Nigeria (2014); Central Bank of Nigeria (2015) in the year 2014, the BOPs account noted a deficit equal to 1.7 per cent of gross domestic product, which revealed a decrease of foreign reserves. The decrease in current account was caused mainly by export earnings, from $15,262.8$ billion naira in 2013 to $12,988.3$ billion naira in 2014 and rising import bills, from 8,628.7 billion naira in 2013 to $9,686.8$ billion naira. The external account was adversely affected by instability in the global prices of crude oil in 2015 and little entry of foreign exchange into the country. Consequently, the external sector also documented BOPs deficit of N1,150.13 billion, corresponding to 1.4 per cent of gross domestic product in 2015. Put succinctly, available data shows that Nigeria has been experiencing deficits in the BOPs in recent years. For instance, balance of payments stood at 349.1 in 1985 . In 1990 and 1995 the country recorded a deficit of $-5761.9 \mathrm{M}$, $-195316.3 \mathrm{M}$ respectively. In the year 2000, balance of payments experienced an increase of 314139.2M. In 2005, balance of payments experienced a decrease of -2394864.31M. However, in 2010 and 2015 balance of payments stood at 2298564.44M and -5.400 , oooM respectively 
To solve the problem of unfavourable BOPs, the Nigerian government had introduced numerous economic policies over the years. For example, in 1986, the government introduced Structural Adjustment Programme (SAP). According to Gbosi (2011) one of the major reasons why Nigeria adopted the SAP in 1986 was to enable her obtain credit facilities from the International Monetary Fund to finance BOPs deficits. Unfortunately, even after the acceptance of the IMF-World Bank structural adjustment programme, the Nigerian economy is still in bad shape. Strictly speaking, the Nigerian economy is married with high rate of inflation, mass unemployment, huge public debt, sluggish economic growth, unfavourable BOPs and sharp decrease of the naira exchange rate.

Despite the fiscal policy measures (capital expenditure, corporate income tax policy and external debt policy) introduced over the years to tackle the troublesome deficit in the country's BOPs. The problem of BOPs still persisted. The above state of affairs raised pertinent questions: what is the relationship between government capital expenditure and BOPs in Nigeria? What is the relationship between corporate income tax and BOPs in Nigeria? What is the relationship between external debt and BOPs in Nigeria? Answers to these questions were the major concern of this work. The broad objective of this paper was to examine the effect of fiscal policy on BOPs in Nigeria from 1980 to 2017.

\section{Literature Review}

\subsection{Conceptual Issue}

Fiscal policy is associated with Keynesian economic theory and policy. Keynesians traditionally view fiscal policy as a technique to fine-tune total spending and guard citizens from turbulent swings in their well-being. Akpakpan (1994) sees it as the deliberate use of the income and expenditure of government to influence the level of economic activities in the country. According to Gbanador (2007) fiscal policy entails government's management of the economy through the manipulation of its income and spending power to achieve certain desired macroeconomic objectives (goals). Furthermore, it can be expansionary or contractionary in nature. An expansionary fiscal policy involves increase in government expenditure and/or decrease in taxes with the aim of stimulating aggregate demand and hence the economy. But the reverse is the case for contractionary fiscal policy. Moreover, both expansionary and contractionary fiscal policy can be employed to correct BOPs disequilibrium. A BOPs deficit can be rectified by reducing government spending and increasing taxes. A reduction in government expenditure will reduce investment and consumption of the public; this will lead to a decrease in income and imports of the country. Moreover, an increase in taxes will reduce households' income leading to a decrease in the demand for quality goods and services. Because of the reduction in demand, prices will fall and this may boost exports. The end result will be an improvement in balance of trade, the country's current account balance and BOPs.

In addition, it is possible to rectify BOPs surplus by reducing taxes and increasing government spending. A decrease in taxes will lead to a rise in disposable income, and the demand for goods and services will increase. Likewise, a meaningful increase in the expenditure of the government will cause the overall demand for goods and services to increase. This will trigger an increase in income and demand, it may discourage exports. Following this approach, an expansionary fiscal policy can reduce BOPs surplus or worsen it.

Furthermore, a nation's international economic balance involves all of the economic transactions that residents of a nation enter into with residents of other nations during a specific time period. The most important tool for the analysis of the external economic position of a nation is the BOPs statement. The BOPs is defined as an accounting statement that sums up all the economic dealings between people of one country and people of other countries. Strictly speaking, it is the overall economic dealings between one country and other countries. Gbosi (2005) asserted that the balance of payments is among other three records of international economic dealings between countries. The three major components of the BOPs are the current account, capital account and official statement balance. The first account (i.e., current) includes dealings where payments are income for a recipient country. They include visible goods, invisible services, remittances, payment of factors etc.

The second (i.e., capital) account records asset transaction. It enables us to know the volume of investment that is made by Nigerian nationals as well as the government in other countries. On the other hand, the official statement account primarily aimed at matching any balance in the current or capital account. Whenever a country's payments exceed her receipts from her foreign transactions, balance of payments becomes unfavourable. This will of course lead to the depletion of her external reserves. Furthermore, if such an adverse condition continues for a long time, pressure will be mounted on the worth of her home currency thereafter leading to depreciation of the home currency. This has been the state of the Nigeria Naira in recent years (Gbosi., 2015). Moreover, a country may record surplus or deficit BOPs. Importantly, BOPs of a country is in surplus when the revenue from export exceeds the payment for import and negative when the reverse is the case. A balance of payment disequilibrium may either be positive or negative (Gbosi, 2005).

The approach towards solving BOPs trouble relies on its cause. For instance, if the BOPs trouble is triggered by a deficit on the current account, which reveals that the country has imported more than it has exported, the country will have to endeavour to reduce its imports and increase its exports. To be precise, the measures which could help a country in achieving this objective include exchange rate control, i.e., controlling access to foreign currencies, import restrictions through tariffs and quotas, stimulation of local production (with improvements in the quality of output) in order to reduce the need to import goods from other countries, stimulation of export production to increase exports earnings. To achieve this, people involved in production will have to try to produce high quality products, and do so efficiently. Put succinctly, the country can adopt economic policies that would ensure macro-economic balances, institute a culture of policy stability, enhance non-oil exports, and develop adequate debt servicing capacity through the enhancement of domestic productivity.

Over the years, the government of Nigeria has employed a number of approaches to solve the problem of balance of payments disequilibrium. For instance, from 1975 to 1980 under the period of regulation in Nigeria, fiscal policy measure adopted by the government includes import liberalization for certain specific commodities, relaxing all administrative controls and removing non-tariff barriers to cross border trade. Other measures included reducing import and excise duties where they were actually important (Lambo, 1987). Meanwhile, in 1979, the country placed some commodities on the prohibition list at the beginning of the plan; the Nigerian 
economy was faced with some difficulties because of the oil glut in the world market. The total amount and prices of the country's crude oil fell extensively; and this led to BOPs deficit. Supporting this, Adedokun (2016) argued that in the early 1980 s the fall in the price of crude oil resulted in oil revenue shock in Nigeria, coupled with unabated preferences for imports. This resulted in current account deficit as revenue from exports was inadequate to offset the bills accruing from imports. During this period the country witnessed a decline in capital inflows as many countries of the world were battling with the effects of slower economic growth. This led to a full blown balance of payments crisis and huge debt profile in Nigeria. To put the situation under control, the government put under license the importation of some commodities while others were banned completely.

From 1980 to 1985 , the key objective of fiscal policy was to stimulate domestic production. To achieve this policy goal, several fiscal measures were adopted by the federal government. For instance, the Income Tax Management Act of 1981 was amended. In October $1^{\text {st }} 1985$ the Federal Military Government declared a state of National Economic Emergency for a period of 15 Months. The National Economic Emergency Decree empowered the President (Head State) to issue orders and legislations which aimed at stimulating the economy during the period of the emergency.

The head of state introduced several fiscal measures. For example, deduction which varied from two to fifteen percent from all incomes including rent, dividends as well as salaries and wages of employees in private and public sectors including the military were made. The deductions were made and paid into the Economic Recovery Fund at the Central Bank of Nigeria. A committee headed by the Federal Director of Budget was set up to manage the fund. The decree also forbade the importation of wheat and rice. This action forced the price of rice to increase substantially. Even after the Economic Emergency period, there had not been any meaningful fall in the price of rice and other basic agricultural commodities in Nigeria. Rather, there was a sharp rise in the prices of goods and services. Apart from high inflationary burdens, high levels of unemployment, external sector instability, and other macroeconomic problems persisted during the period (Gbosi, 2012). Also, duties were once more increased in 1981, while, in 1984 the range of import duties was reduced and permitted to last for three years.

Adjustments were made in customs and excise tariff to give improvement to locally assembled agricultural equipment in 1986, while a number of items were placed under ban. Furthermore, fiscal policy in Nigeria under deregulation period was also aimed at achieving macroeconomic objectives. The main macroeconomic troubles under SAP were those of increasing rates of inflation, unemployment, huge debt and balance of payments disequilibrium. Thus, fiscal policy was planned to significantly reduce budget deficit, guarantee increase in revenue and advance effective control and efficiency in fiscal operations (Central Bank of Nigeria, 1985).

In 1987, a major fiscal policy measure adopted was the contribution of the National Economic Recovery Fund (NERF) which was established in 1985. As part of actions to reduce the influence of inflationary burdens on workers in the civil service, the government restored and in specific cases augmented some fringe benefits of workers. A number of fiscal measures were introduced to stimulate the economy. For example, inflationary package of 250 million naira was made available, to add up to the 600 million naira built in deficit during the financial year. The complete tariff structure was accepted (planned to last for seven years), partly to make available advanced degree of protection to local industries. Excisable products were reduced from 412 to 182 . The harmonized coding system and commodity were incorporated into the new tariff structure while anti-dumping tariff on certain items came into force (Anyanwu, Oyefusi, Oaikhenam, \& Dimowo, 1997). Some of the measures employed in 1988 were reserved in 1989 with the aim of attaining favourable balance of payments.

In an attempt to encourage balance in fiscal target, certain all-purpose principles were designed to improve the effectiveness of government spending from 1990 to 1993. Most of the economic measures brought into use in the 1994 budget were anticipated to address slow growth in the productive sectors, check the weight of inflation and correct unfavourable BOPs. Momentously, the main policy objectives of 1994 budget were the promotion of selfsustaining growth in the real sector under a regime of fixed exchange and interest rates, coupled with tight monetary and fiscal policies. Fiscal policy adopted in 1994 did not achieve their desired objectives. Therefore, a policy of "guided deregulation" was adopted by the government in 1995. The main objective of the policy was to strengthen and buildup foreign reserves to enhance confidence in the Nigerian economy. This would subsequently strengthen the naira and make a way for its final convertibility (Central Bank of Nigeria, 1995).

Since the 1990's, government fiscal operations in Nigeria have been branded by persistent deficits. Fiscal policy was then designed to expand agriculture production which in turn will help to reduce food import, reduce inflation, expand revenue base, and to improve resource allocation. Thus, from 1996 to 1998, the country's fiscal policy aimed at upholding finest equilibrium between revenues and expenditures. The country also designed fiscal incentives to promote output growth in the economy and hence reduce importation of goods and services. Because of increasing demand for increased public expenditures, efforts were geared towards enhancing efficiency in tax collection. Measures for revenue mobilization included tax reforms to recoup tax administration especially in tax collection. A number of measures were designed to reduce public expenditures as a strategy to achieving effective resource mobilization for the economic recovery programmes. The stance of fiscal policy in this regard since 1999 had been restrictive in nature. Some of the fiscal measures implemented in 1999, were retained in 2000 and 2001 respectively. However, since 2005, the main objective of fiscal policy thrust of 2005 was consistent with the provisions of the National Economic Empowerment Development Strategies (NEEDS). The NEEDS is targeted at improving the quality of life and increasing infrastructural facilities, and employment generation.

The fiscal thrust in 2007 was focused on strengthening growth included development strategy. As outlined under the NEEDS which was formulated within the context of the medium term expenditure framework. The strategy was directed towards eliminating infrastructural deficiencies. Over the years, these infrastructural deficiencies had hindered business operational efficiency, improving the quality of life of the citizenry and accelerating investment in basic infrastructure and human capita. It was also targeted at addressing weaknesses in planning process in the country to support the development programmes of the government. The seven points Agenda of the Late, President Yar'adua's administration reinforced the need for infrastructural (water, power, roads) and social (wealth and education) development with ultimate aim of achieving adequate economic growth, favourable balance of payments, etc. The fiscal actions employed in 2007, were retained in 2008 , and 2009 
respectively. But the financial policy thrust of the 2010 budget was intended to stimulate economic recovery from the negative effects of the global economic and financial crisis (Central Bank of Nigeria, 2010).

The government also adopted Transformation programmes in 2011 to 2015 with increased spending outlay; the budget was to transform the socio-economic fortunes of the country by implementing relevant measures to address the challenges of the economy. This was to be achieved through targeted fiscal interventions in important sectors, mainly critical infrastructure in order to create an enabling environment for the hastening of sustainable economic growth and development driven by non-government sector. This also was a road map for addressing critical challenges of BOPs deficits in Nigeria. During the period 2015 to 2018 , the government adopted both expansionary and contractionary fiscal policy to redress the problem of imbalance in the BOPs. Fiscal actions were also put in place to encourage growth in the economy and hence reduce importation of goods and services. The government also imposed a ban on the importation of some goods.

Yet, the country's balance of payments trouble has remained worse because of the pitiable non-oil export performance, persistent decline in the country's foreign exchange, high import, preference for foreign goods and services over domestic goods and services, stagnated agriculture, pressure of inflation, inefficiency of the manufacturing sector and unstable oil prices in the foreign oil market. Hence, it is necessary to consciously examine how fiscal policy has impacted on BOPs in Nigeria from 1980 to 2017.

\subsection{Theoretical Reviere}

Keynes in the twentieth century made a strong argument for the important role of fiscal action and submitted that active public policy could be effective in managing an economy. The approach has it that an increase in public spending and/or decrease in taxes will stimulate total demand and hence the economy. Therefore, fiscal policy (both expansionary and contractionary fiscal policies) can be employed to correct imbalance in the BOPs. For instance, a contractionary fiscal policy can be employed to solve the problem of BOPs deficit. Also, an expansionary fiscal policy can be employed to solve the problem of surplus in the BOPs. At the same time, Keynes submitted that government borrowing will add to the wealth of the country which will increase spending. The Keynesian regression function for balance of trade could simply be presented as:

$(\mathrm{X}-\mathrm{M})_{\mathrm{t}}=\alpha_{\mathrm{o}}+\alpha_{1} \mathrm{Y}_{\mathrm{t}}+\alpha_{2} \mathrm{P}_{\mathrm{t}}+\alpha_{3} \mathrm{EXR}_{\mathrm{t}} \quad$ (i). Where; $\mathrm{X}=$ exports, $\mathrm{M}=$ imports, $\mathrm{Y}=$ level of income, $\mathrm{P}=$ price level, $\mathrm{EXR}=$ exchange rate and $\mathrm{t}=$ time period. Furthermore, based on the observation of Malindretos $(1991)$ the Keynesian regression function for the official reserves transaction balance could simply be written as:

$\mathrm{IR}_{\mathrm{t}}=\alpha_{\mathrm{o}}+\alpha_{1} \mathrm{Y}_{\mathrm{t}}+\alpha_{2} \mathrm{P}_{\mathrm{t}}+\alpha_{3} \mathrm{MS}_{\mathrm{t}}+\alpha_{4} \mathrm{i}+\alpha_{5} \mathrm{EXR}_{\mathrm{t}} \quad$ (ii). Where; IR $=$ the international reserves, $\mathrm{P}=$ the price level, MS = money supply, $\mathrm{Y}=$ level of income, $\mathrm{i}=$ the interest rate and $\mathrm{EXR}=$ exchange rate. The importance of the Keynesian approach to balance of payments is that it sees trade balance, as the most significant account of the BOPs. The explanatory variables - price, level of income, exchange rate, money supply and interest rate will first of all influence the trade balance and then the BOPs. This implies that BOPs disequilibrium occurs because of the imbalance of real forces (Wanniski, 1975). Therefore, the Keynesian model focused on the actual account (trade balance) which is autonomous and the official reserves transaction balance is therefore the accommodating account. In the light of the above, this work adopted the Keynesian approach to BOPs (i.e., this work hangs on the Keynesian approach to BOPs) which made it clear that an increase in the government consumption expenditure will lead to an increase in total demand, increase in investment, income, employment and promising trade balance.

According to Onuchuku and Obayori (2018) Keynesian approach to BOPs was based on elasticities and absorption theories (approaches) of balance of payments. The elasticities approach to BOPs emphasizes the effect of price changes. Depreciation of a currency or appreciation of it may change the price of the domestic currency paid for imports and what is received for exports, consequently leading to variations in the amount of imports demanded and exports supplied. The amount by which the quantity of imports demanded and the quantity of exports supplied (and, therefore, the balance of payments) change is determined by the elasticity of export supply and the elasticity of import demand. On the other hand, the absorption approach emphasizes a country's real income and expenditures as determinants of its BOPs and the exchange value of its currency. According to the approach, if a country's actual income surpasses the quantity of goods and services that it takes (absorbs), then the country will run a current account surplus. If a country's actual income is less than the quantity of goods and services it takes, then the nation will run a current account deficit. If actual income and absorption are equal, the nation's current account will be balanced. Importantly, it illustrates that if real income rises faster than absorption, then exports rise relative to imports, the country's balance of payments improves, and the domestic currency appreciates. If absorption rises faster than real income, then imports rise relative to exports, the country's BOPs deteriorates, and the domestic currency depreciates. The two types of policy instruments in the absorption model the absorption instruments and the expenditure-switching instrument, may have negligible effects on a nation's current account imbalance. Hence, it is unclear if these instruments will increase real income relative to absorption.

\subsection{Review of Empirical Literature}

In Nigeria, only a handful of empirical studies have specifically investigated the influence of fiscal policy on balance of payments. In this study, only those that are directly relevant to the study were discussed.

\subsection{Government Capital Expenditure and Balance of Payments}

Onuchuku and Obayori (2018) applied vector error correction technique to investigate the impact of fiscal policy on BOPs in Nigeria. The result revealed that increase in capital spending and external debt will cause a favourable balance in BOPs. Meanwhile, a percentage increase in company income tax will decrease BOPs.

Using data from 1980 to 2012, Brown and Bidemi (2015) applied co-integration and error correction mechanism methods to investigate the extent to which fiscal policy measures have influenced Nigeria's BOPs position. The result revealed that the influence of tax revenue on BOPs in Nigeria to be positive and significant. It also revealed the influence of government spending, as well as debt on BOPs to be negative and significant. 
Egwaikhide (1997) looked at how budget deficit has influenced Nigeria's current account balance. The researcher constructed a macro-econometrics model that captured the noticeable interrelationships between credit creations, budgetary developments by the government and current account balance. Numerical evidence suggested that policy regarding budget affects the country's current account balance. To be precise, simulation tests showed that budget deficit, caused by increased spending, will lead to a deterioration of current account.

\subsection{Corporate Income Tax and Balance of Payments}

Azubike (2016) examined policies that affect the position of Nigeria's balance of payments. Specifically, policies regarding exchange rate, tariff and non-tariff were considered. A number of proxies were employed to explain the influence of the policies on BOPs. They include; indirect tax as a proxy for tariff policies, money supply, export and interest rate as a proxy for non-tariff policies, and exchange rate. The study employed ordinary least squares method of econometrics. The result revealed that the export, exchange rate and indirect tax satisfy the economic apriori expectations, while money supply and interest rate did not satisfy the apriori expectations.

Atan (2013) used descriptive, inferential statistical and OLS methods to examine the consequence of managing the Nigerian economy through taxation and its influence on macroeconomic aggregates, especially BOPs from 1970 to 2008. The findings indicated that the historical trend in BOPs has no meaningful and insignificant response to tax policy. The study obtained a positive association between tax policy and BOPs. Further, the researcher found that policy regarding taxation was ineffective in tackling the problem of BOPs because of inconsistency in the use of tax measures.

Onuchuku, Ofoezie, and Nteegah (2006) examined fiscal policy measures and macroeconomic stability in Nigeria from 1980-2004. The researchers used multiple regressions to analyze the influence of government expenditure, revenue and debt on GDP, BOP, inflation and unemployment. The outcome showed a weak association between fiscal policy variables and macroeconomic stability. Specifically, a negative relationship exists between government tax and balance of payments.

Anyanwu (1997) used secondary data from 1981 to 1996 and ordinary least squares technique to investigate the influence of taxes on BOPs in Nigeria. The result showed that taxes significantly influence Nigeria's BOPs. This means that tax policy measure to encourage export production in order to increase the exports earnings will help to solve BOPs problem in Nigeria.

\subsection{External Debt and Balance of Payments}

In Kenya, Muli and Ocharo (2018) used Granger causality technique to analyze the association between external debt servicing and current account balance. External debt service was found to granger caused current account balance.

Also, Magero (2015) used Vector Error Correction Model to find out how total debt servicing has influenced macroeconomic performance in Kenya. The result showed that debt servicing significantly influenced on macroeconomic performance.

Morsy (2012) used inter-temporal approach cum panel data to examine the association between currency crisis and current account balance in oil exporting countries. The outcome revealed that current account balance was influenced by external debt.

In Greece, Mbanga and Sikod (2008) used vector autoregressive technique to examine the impact of external debt servicing on macroeconomic variables from 1995 to 2006. The result showed that external debt servicing and inflation rate affected the development of current account greatly.

In Central and East European Union, Herrmann and Jochem (2005) used Feasible Generalized Least Squares estimation technique to investigate the influence of selected macroeconomic variables on current account balance. The result showed that current account balance and external debt services have a negative relationship.

Zaidi (1985) used cross-sectional time-series data drawn from 12 developing countries to examine the association between fiscal deficit and current account balance. Although the results revealed a direct association between the variables, the causality tests showed bidirectional causality between fiscal deficits and the current account deficits for Philippines and South Korea, but a unidirectional causality running from the current account deficit to budget deficit for Thailand and Greece. Meanwhile, the variables were statistically independent between 1972 and 1980 in Brazil.

The examination of the previous works done that are connected to this present research showed that, there are differences in opinions and empirical findings regarding the impact of fiscal policy on BOPs, especially in countries that are developing like Nigeria. For instance, the results of the analysis of Atan (2013); Brown and Bidemi (2015); Onuchuku and Obayori (2018) showed that that in Nigeria, government capital expenditure and tax revenue (policy) have significant and positive effect on BOPs. Furthermore, the empirical work of Onuchuku et al. (2006) revealed a weak relationship between fiscal policy variables and macroeconomic stability. Specifically, tax revenue and BOPs have negative relationship.

The difference in empirical findings regarding the impact of fiscal policy on BOPs is of serious concern, especially in developing countries like Nigeria; and this necessitates further researches. Thus, this provides a good reason to empirically ascertain how fiscal policy has impacted on BOPs of Nigeria from 1980 to 2017. Moreover, as much as the above studies are commendable, the basic questions remain as: what is the relationship between government capital expenditure and BOPs of Nigeria? What is the relationship between corporate income tax and BOPs of Nigeria? What is the relationship between external debt and BOPs of Nigeria? These questions beg for answers and this study therefore appealed to empirical evidence to resolve these questions.

Nevertheless, in the works of some scholars including Onuchuku and Obayori (2018) etc., VECM econometric method was used without paying attention to their unit root result which do not support the use of VECM but supports ARDL model. None of the scholars used ARDL method to analyze their data. Secondly, none of these scholars covered the period of 1980 to 2017 . Therefore, this study systematically looked at how fiscal policy has influenced Nigeria's BOPs from 1980 to 2017 by using the econometric technique of Autoregressive Distributed 
Lag (ARDL) model to assist determine the relationship amongst variables that are included in this investigation.

\section{Methodology}

The data for this study were sourced from the Statistical Bulletin of various issues of the Nigeria's apex bank. The data covered the period 1980-2017. In addition, the techniques of Augmented Dickey Fuller (ADF) unit root test and Autoregressive Distributed Lag (ARDL) were employed to investigate the effect of fiscal policy on balance of payments in Nigeria. Normality test was also carried out to ascertain the reliability of the model for policy purposes.

\subsection{Model Specification}

The study developed an econometric model aimed at capturing the relationship between balance of payments and fiscal policy variables in Nigeria, in line with the theoretical and empirical literature reviewed. Importantly, the model of Onuchuku and Obayori (2018) was adapted. The model of Onuchuku and Obayori (2018) is in the form of Equation 1:

$$
M=f(G, T, D)
$$

In Equation 1, M is the BOPs, $\mathrm{G}=$ government expenditure, $\mathrm{T}=$ Corporate Income Tax and $\mathrm{D}$ is external debt; but with slight modification. The model for this study is presented in Equation 2.

$$
\mathrm{BOP}=\mathrm{f}(\mathrm{GCE}, \mathrm{CIT}, \mathrm{EXD}, \mathrm{EXR}) \quad \text { (2). }
$$

From the above functional model or association between the dependent and explanatory variables, the econometric form of the model is presented in Equation 3:

$$
\mathrm{BOP}_{\mathrm{t}}=\mathrm{a}_{\mathrm{o}}+\mathrm{a}_{1} \mathrm{GCE}_{\mathrm{t}}+\mathrm{a}_{2} \mathrm{CIT}_{\mathrm{t}}+\mathrm{a}_{3} \mathrm{EXD}_{\mathrm{t}}+\mathrm{a}_{4} \mathrm{EXR}_{\mathrm{t}}+\mathrm{u}_{\mathrm{t}}
$$

From Equation 3:

$\mathrm{BOP}=$ Balance of Payments (N'million).

GCE $=$ Federal Government Capital Expenditure (N'million).

CIT $=$ Corporate Income Tax (N'million).

EXD = External Debt (N'million).

$\operatorname{EXR}=$ Exchange Rate $(\$)$.

Apriori Expectation: On the apriori: GCE, CIT, EXR and EXD $>0$ (i.e., $a_{1-} a_{4}>0$ ).

\subsection{Unit Root Test}

To avoid false regressions outcomes the ADF method was employed based on the building of Equation 4:

$$
\Delta \mathrm{BOP}_{\mathrm{t}}=\alpha_{\mathrm{o}}+\alpha_{1} \mathrm{BOP}_{\mathrm{t}-1}+\Sigma \alpha_{1} \Delta \mathrm{BOP}_{\mathrm{i}}+\delta_{\mathrm{t}}+\mathrm{u}_{\mathrm{t}}
$$

In Equation $4, \mathrm{BOP}=$ time series, $\mathrm{t}=$ linear time trend, $\Delta=$ the first difference operator, $\alpha_{0}=\mathrm{a}$ constant, $\mathrm{n}=$ the optimum number of lags in the explanatory variables and $\mathrm{u}=$ random error term.

\subsection{Estimation Technique}

The study employed Autoregressive Distributed-Lag (ARDL) model as the estimation technique. This is because; the ARDL helps to showcase the short and long-term relations between the fiscal policy variables and BOPs variable in the model. The ADF test precedes ARDL test. The ARDL model for this study is presented in Equation 5;

$$
\begin{aligned}
& \Delta B O P_{t, j}=\alpha_{0}+\alpha_{1} G C E_{t-1, j}+\alpha_{2} C I T_{t-1, j}+\alpha_{3} E X D_{t-1, j}+\alpha_{4} E X R_{t-1, j}+\sum_{i=1}^{n 1} b_{1 i, j} \Delta B O P_{t-1, j} \\
&+\sum_{i=0}^{n 2} b_{2 i, j} \Delta G C E_{t-1, j}+\sum_{i=0}^{n 3} b_{3 i, j} \Delta C I T_{t-1, j}+\sum_{i=0}^{n 4} b_{4 i, j} \Delta E X D_{t-1, j}+\sum_{i=0}^{n 4} b_{5 i, j} \Delta E X R_{t-1, j} \\
&++\mu_{t}
\end{aligned}
$$

In Equation 5, BOP $=$ Balance of payments, GCE $=$ Government Capital Expenditure, CIT = Corporate Income Tax, EXD = External Debt and EXR = Exchange Rate.

\section{Results and Discussion}

The ADF method was used to test for the stationarity of the variables and the result of the test is presented in Table 1 .

\begin{tabular}{c|c|c|c|c|c|c}
\hline Variables & $\begin{array}{c}\text { ADF Test } \\
\text { Statistic at } \\
\text { Level }\end{array}$ & $\begin{array}{c}\text { ADF Test } \\
\text { Critical } \\
\text { Value at 5\% } \\
(\mathbf{l e v e l )}\end{array}$ & $\begin{array}{c}\text { Order of } \\
\text { Integration }\end{array}$ & $\begin{array}{c}\text { ADF Test } \\
\text { Statistic at } \\
\mathbf{1}^{\text {st }} \\
\text { Difference }\end{array}$ & $\begin{array}{c}\text { ADF Test } \\
\text { Critical } \\
\text { Value at 5\% } \\
\left(\mathbf{1}^{\text {st }} \mathbf{\text { Diff. } )}\right.\end{array}$ & $\begin{array}{c}\text { Order of } \\
\text { Integration }\end{array}$ \\
\hline BOP & -4.370463 & -3.536601 & Stationary & - & - & $1(0)$ \\
\hline CIT & -0.978360 & -3.557759 & Not Stationary & -6.538290 & -3.587527 & $1(1)$ \\
\hline EXD & -1.786316 & -1.950394 & Not Stationary & -3.833363 & -3.540328 & $1(1)$ \\
\hline GCE & -3.369334 & -3.536601 & Not Stationary & -8.036383 & -3.540328 & $1(1)$ \\
\hline EXR & -2.094986 & -3.536601 & Not stationary & -6.033776 & -3.540328 & $1(1)$ \\
\hline Note: BOP, CIT, EXD, GCE and EXR as previously defined.
\end{tabular}

The unit root test result presented in Table 1 shows that at 5 per cent level of significance the variables were stationary; BOP was stationary at level 1(0). While, CIT, EXD, GCE and EXR were stationary at first difference 
1(1). Given that the variables were integrated of order $1(0)$ and $1(1)$. The requirement to fit in an ARDL model to test for long run cointegrating relationship is satisfied and the result of the test is presented in Table 2.

\begin{tabular}{|c|c|c|}
\hline \multicolumn{2}{|c|}{ Model } & F-Statistic $=176.5055$ \\
\hline \multicolumn{2}{|c|}{$\mathrm{F}(\mathrm{BOP}, \mathrm{CIT}, \mathrm{EXD}, \mathrm{GCE}$ and EXR) } & $\mathrm{K}=4$ \\
\hline Critical Values & Lower Bound & Upper Bound \\
\hline $5 \%$ & 2.86 & 4.01 \\
\hline
\end{tabular}

The result in Table 2 reveals a long run relationship amongst BOP, CIT, EXD, GCE and EXR. The reason for this is that computed F-statistic of about 176.5055 is more than the upper critical bounds at $5 \%$ critical values. Therefore, the study rejects the null hypothesis of no co-integration at $5 \%$ significance level for the balance of payments model. Following the establishment of long-run co-integration association among the variables, the long-run and short-run dynamic parameters for the variables were obtained. The results are presented in Tables 3 and 4 .

Table-3. Estimated ARDL Long Run Coefficients. Dependent Variable: BOP ARDL (4, 4, 4, 3, 4).

\begin{tabular}{c|c|c|c}
\hline Regressors & Coefficient & t-Statistic & P-Value \\
\hline CIT & 1.246645 & 12.842794 & 0.0000 \\
\hline GCE & 2.175758 & 11.062710 & 0.0000 \\
\hline EXD & 0.685499 & 56.997111 & 0.0000 \\
\hline EXR & -30417. & -31.921900 & 0.0000 \\
\hline
\end{tabular}

Note: BOP, CIT, EXD, GCE and EXR as previously defined.

The result in Table 3 shows that the cointegration coefficients of corporate income tax, government capital expenditure and external debt have positive and significant association with BOPs. What this suggests is that a unit increase in corporate income tax, government capital expenditure and external debt will raise the country's balance of payments by $1.246645 \mathrm{M}, 2.175758 \mathrm{M}$ and $0.685499 \mathrm{M}$ respectively. The result also pointed out that exchange rate has negatively influenced BOPs. Meanwhile, the rate of exchange is statistically significant. This means that a weak value of the naira in relation to dollar will decrease the balance of payments position of Nigeria.

\begin{tabular}{c|c|c|c}
\multicolumn{2}{c}{ Table-4. Error Correction Result for the Selected ARDL Model ARDL $(4,4,4,3,4)}$. \\
\hline Regressors & Coefficients & t-Statistic & P-Value \\
\hline CIT & 4.424403 & 5.887983 & 0.0002 \\
\hline GCE & 5.047935 & 8.158428 & 0.0000 \\
\hline EXD & -0.257748 & -2.683402 & 0.0230 \\
\hline EXR & -4449.075 & -2.411285 & 0.0366 \\
\hline ECM (-1) & -1.368689 & -10.546516 & 0.0000 \\
\hline R-squared = 0.999889 & F-statistic $=$ & Akaike info criterion $=$ & Durbin-Watson \\
Adjusted R-squared = & 3930.672 & 23.47755 & stat $=1.761907$ \\
O.999635 & Prob(F-statistic $=$ & Schwarz criterion $=$ & \\
& 0.000000 & 24.55498 & \\
\hline
\end{tabular}

Note: BOP, CIT, EXD, GCE and EXR as previously defined.

The error correction term in Table 4 is negative and statistically significant. This shows it adjustment from short run equilibrium to long-run equilibrium in the dynamic model. The Durbin Watson (DW) value of 1.761907, which is approximately 1.8 , suggests that autocorrelation is not a problem to the model. The F-statistics also reveals that the overall model is statistically significant.

Moreover, coefficients of corporate income tax and government capital expenditure have positive relationship with BOPs. What this means is that, a unit increase in corporate income tax and government capital expenditure will raise the country's balance of payments by $\$ 4.424403 \mathrm{M}$ and $5.047935 \mathrm{M}$ respectively. The result also reveals that exchange rate and external debt have negative relationship with BOPs. What this suggests is that a unit increase in external debt will decrease the country’s BOPs by $0.257748 \mathrm{M}$. However, a weak value of the naira in relation to dollar will decrease the balance of payments position of Nigeria by 4449.075M. Furthermore, all the explanatory variables - corporate income tax, government capital expenditure, external debt and exchange rate are statistically significant.

Therefore, the study accepts the alternative hypotheses which state that government capital expenditure, corporate income tax, exchange rate, and external debt have significant relationship with BOPs in Nigeria. This suggests that corporate income tax government capital expenditure, external debt and exchange rate have meaningfully affected Nigeria's BOPs during the period of study. This also means that, in the short run, appropriate policies regarding corporate income tax, government capital expenditure, external debt and exchange rate have the ability to meaningfully influence Nigeria's balance of payments. These findings corroborate the empirical works of Azubike (2016) as well as Onuchuku and Obayori (2018) who unambiguously affirmed that fiscal measures have significant impact on Nigeria's balance of payments. 


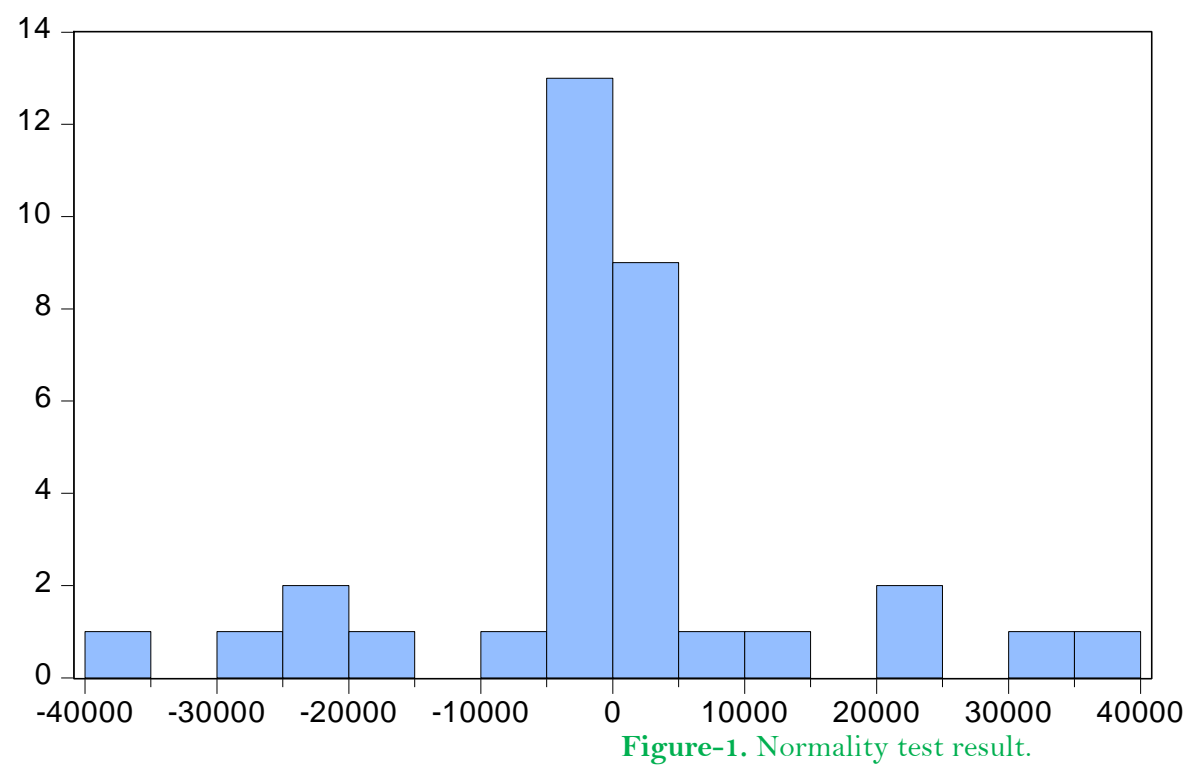

\section{Series: Residuals \\ Sample 19842017 \\ Observations 34}

\begin{tabular}{lc} 
Mean & $-7.97 \mathrm{e}-10$ \\
Median & -14.32928 \\
Maximum & 37847.66 \\
Minimum & -37476.59 \\
Std. Dev. & 15197.42 \\
Skewness & 0.141159 \\
Kurtosis & 4.202801 \\
& \\
Jarque-Bera & 2.162449 \\
Probability & 0.339180 \\
\hline
\end{tabular}

The Jarque-Bera statistic shows that the error term is normally distributed at five per cent. This is because the probability value of 0.339180 is larger than the five per cent conventional level.

\section{Conclusion and Recommendations}

Fiscal policy plays a significant role in achieving basic macroeconomic objectives, especially equilibrium in the BOPs. Therefore, this study carefully investigated the effect of fiscal policy on balance of payments in Nigeria from 1980 to 2017. The study used data on balance of payments, corporate income tax, government capital expenditure, external debt and exchange rate from the statistical bulletin of Nigeria's apex bank and employed ARDL method of econometrics to analyze the data. The findings showed that in the long run, corporate income tax, government capital expenditure and external debt have positive and significant effect on balance of payments in Nigeria. At the same time, the rate of foreign exchange has a negative and meaningful effect on BOPs in Nigeria. Furthermore, in the short run, corporate income tax and government capital expenditure have positive and significant effect on BOPs in Nigeria. Meanwhile, external debt and exchange rate have negative and significant effect on balance of payments in Nigeria. The study therefore concluded that fiscal policy in Nigeria has a meaningful effect on BOPs during the period of study. Thus, fiscal policy is effective in achieving favourable BOPs in Nigeria. Therefore, the study made the following recommendations:

i. Government should increase its capital investment in revamping all ailing industries; encourage domestic industries, locally made goods and exportation of manufactured or finished goods. The country should also abstain from excessive consumption of foreign goods and services that are not essential.

ii. Government should remove all loopholes and ensure all companies located in the country are registered to make tax collection easy, and punish any company that does not remit income tax adequately. At the same time, favourable corporate tax policies should be encouraged in order to enhance production in the economy.

iii. Government should ensure that national debt is incurred on reasonable economic terms and invest in viable projects which will benefit the economy by enhancing its growth and future economic independence but avoid unnecessary and unproductive borrowing that will hurt the economy.

iv. Monetary authorities should maintain the current exchange rate system (managed floating exchange rate system) to redress the problem of exchange rate variation in Nigeria.

\section{References}

Adedokun, S. A. (2016). Balance of payments equilibrium: A test of Marshall-Lerner condition in Nigeria. FUTA Journal of Management and Technology, 1(2), 34-44.

Akpakpan, E. B. (1994). How to save the Naira in Nigeria, macroeconomics action. Abak: Belpot Nig. Co.

Anyanwu, J. C. (1997). Nigerian public finance. Nigeria: Joanee Educational Publishers.

Anyanwu, J. C., Oyefusi, A., Oaikhenam, H., \& Dimowo, F. A. (1997). The structure of the Nigerian economy. Onitsha: Joanee Educational Publishers Ltd.

Atan, J. A. (2013). Taxation and balance of payments in Nigeria (1970 - 2008). IOSR Journal of Business and Management, 13(2), 23-32.

Azubike, A. (2016). Balance of payments and policies that affects its positioning in Nigeria. Munich Personal RePEc Archive (MPRA), Paper No. 74841 .

Brown, E. D., \& Bidemi, O. J. (2015). Fiscal policy measures and balance of payments in Nigeria. Journal of Global Economics, 3(4), 1-6. Available at: https://doi.org/10.4172/2375-4389.1000161.

Central Bank of Nigeria. (1985). Annual Report and Statement of Account, Lagos.

Central Bank of Nigeria. (1995). Annual Report and Statement of Account, Abuja.

Central Bank of Nigeria. (2010). Annual Report, Abuja.

Central Bank of Nigeria. (2014). Annual Economic Report 2014.

Central Bank of Nigeria. (2015). Annual Economic Report 2015.

Conway, E. (2009). 50 economics ideas you really need to know. New York: Quetons.

Egwaikhide, F. O. (1997). Effects of budget deficit on the current account balance in Nigeria: A simulation exercise (pp. 1-47). AERC Research Paper No. 70 African Economic Research Consortiums, Nairobi November 1997.

Ekine, N. T. (2011). Macroeconomics: Dimensions of competitive indicators and policy performance. Port Harcout, Rivers State, Nigeria: Dominus Printing Co, \#7 Udi Street.

Gbanador, C. A. (2007). Modern macroeconomics. Port Harcourt: Pearl Publishers.

Gbosi, A. N. (2005). Money, monetary policy and the economy. Akwa Ibom State: Abigap Associates Ltd Confidence Estate 28 Itu Road Uyo.

Gbosi, A. N. (2011). International trade in theory and practice. Port Harcourt: Amethyst \& Colleagues Publishers. 
Gbosi, A. N. (2012). Government policy makers and the Nigerian economy. Port Harcourt: Thompson and Thompson Company Ltd.

Gbosi., N. G. (2015). Contemporary macroeconomic problems and stabilization policies (2nd ed.). Benin City, Nigeria: Spirit and Truth Publishers.

Herrmann, S., \& Jochem, A. (2005). Determinants of current account developments in the central and east European EU member states consequences for the enlargement of the euro area. Discussion Paper Series 1: Economic Studies No 32/2005, Frankfurt am Main: Deutche Bundesbank.

Lambo, T. (1987). The Nigerian economy today. Ibadan: Evans Brothers Ltd.

Magero, O. J. (2015). Total debt servicing and macroeconomic performance in Kenya. Kenyatta University: Unpublished M.A Research Paper.

Malindretos, J. (1991). An examination of the two views of international finance for an advanced, medium-sized, reserve currency country. Advances in Quantitative Analysis of Finance and Accounting, 1(B), 183-2 14

Mbanga, G. N., \& Sikod, F. (2008). The impact of debt and debt-service payment on investment in Greece. Paper presented at the Final Report Presented at the AERC Biannual Research Workshop, 4 April.

Morsy, H. (2012). Current account determinants for oil-exporting countries. Emerging Markets Finance and Trade, 48(3), 122-133. Available at: https://doi.org/10.2753/ree1540-496x480307.

Muli, J. M., \& Ocharo, K. N. (2018). External debt servicing and current account balance in Kenya. International Journal of Development and Sustainability, 7(5), 1688-1710.

Nwokpara, G. (1997). Recent policy measures in foreign exchange management in Nigeria: Implications for the economy. First Bank Review, $5(10), 1-9$.

Onuchuku, O., \& Obayori, E. L. (2018). Fiscal policy and balance of payments in Nigeria. International Journal of Science and Management Studies, 1(4), 74-81.

Onuchuku, O., Ofoezie, K. O., \& Nteegah, A. (2006). Fiscal policy measures and macroeconomic stability in Nigeria. Nigerian Journal of Monetary Economics, 6(7), 68-83.

Umo, J. U. (2012). Escaping poverty in Africa. A perspective on strategic agenda for Nigeria (pp. 527). Unilag Estate, Magodo, Isheri, Lagos, Nigeria: Millennium Text Publishers Limited 14 Science Road.

Wanniski, J. (1975). The Mundell-Laffer hypothesis-a new view of the world economy. The Public Interest, 1(1), 31-52.

Zaidi, I. M. (1985). Savings, investment, fiscal deficit, and the external indebtedness of developing countries. World Development, 13(5), 573588. 